Ethics

Journal

Review

SCHOLARLY COMMENTS ON

\title{
Morality Meet Politics, Politics Meet Morality: Exploring the Political in Political Responsibility
}

Florian Wettstein ${ }^{1}$

A RESPONSE TO Jeffery Smith (2013), "Corporate Human Rights Obligations: Moral or Political?”, Bus Ethics J Rev 1(2): 7-13.

\begin{abstract}
This brief response to Smith focuses on his distinction between moral and political responsibility in general and how it relates to human rights in particular. I argue that the notion of political responsibility as it is used in the debate on political CSR often does not exclude morality but is based on it.
\end{abstract}

JEFFERY SMITH'S THOUGHTFUL comment on my paper (Wettstein 2012) touches on an issue which is indeed in need of clarification: the notion of political responsibility, specifically as it relates to companies. While recent years have heralded a growing and increasingly influential discussion on political CSR (see, e.g., Scherer and Palazzo 2011 for an overview), the notion of political responsibility within that debate has remained rather ambiguous. Thus, in my brief response to Smith, I will focus on his distinction between moral and political responsibility, in general, and how it relates to human rights, in parti-

${ }^{1}$ University of St. Gallen. Email: florian.wettstein@unisg.ch 
cular. My conclusion will be that moral responsibility is not opposed to but often constitutive of the way the notion of political responsibility is used in the debate on political CSR. My response is not meant to advance a counterargument to Smith; rather, it aims at continuing Smith's task of clarifying further the concepts and notions informing the debate on business and human rights and of political CSR.

\section{What is Political About Political Responsibility?}

The debate on the political role of corporations has become more prominent and more diverse in recent years. Scholars within this debate have dealt with the issue both in a more descriptive sense (see, e.g., Crane and Matten 2005) as well as with normative questions of corporate political responsibility (see, e.g., Scherer and Palazzo 2007). Thus, while they are often referred to rather monolithically as a collective of "advocates of political CSR" (Smith 2013: 11), at a deeper level their positions on the issue and specifically their interpretations of political responsibility, which often build the core of their arguments, vary substantially. Particularly, the line between the moral and the political may not always be as clear cut as Smith seems to propose.

Our understanding of political responsibility hinges on our interpretation of the political. Against this background, I believe we can distinguish two basic ideas of political responsibility. The first interpretation assumes the political as the basis or foundation of responsibility. The second interpretation perceives the political as the kind of action required to discharge responsibility. In the following, I will call the first interpretation "politically grounded responsibility." The second interpretation I will call "responsibility for political action.” However, both interpretations are commonly used simply under the banner of "political responsibility."

Politically grounded responsibility is based on political processes, deliberations and agreements. The substance of such responsibility, that is, what the responsibility is a responsibility to or for, is determined by the outcomes of such processes and deliberations. Such outcomes do not need to entail political action or engagement-even something trivial and seemingly apolitical like keeping front yards well groomed can be a political responsibility if it has been determined in a political deliberation process. 
Responsibility for political action is based not on a political, but on a moral, foundation. Its substance, however, is political engagement or activity. Thus, responsibility for political action is a moral responsibility to engage politically. In sum, the political in political responsibility may refer to either its foundation (politically grounded responsibilities) or to its substance (responsibilities for political action).

The responsibility for political action can be further specified as a responsibility for political action in a narrow and in a wide sense. Political action in a narrow sense refers to activities within, through, or directed at formal political - that is, governmental - channels and institutions. The most evident examples of such activities are lobbying or expert consultations by companies or their representatives. Nien-hê Hsieh (2009) has recently advanced such a position with his argument for a corporate responsibility to promote just institutions in contexts in which they are lacking. He refers to the duty not to cause harm as the foundation for such a corporate responsibility to promote just institutions. Thus, while Hsieh (2009: 252) places his argument explicitly within the "paradigm shift" of political CSR, his account of political responsibility rests on a distinctly moral foundation. The activity of promoting just institutions, however, is, at least in some of the instances listed by Hsieh (2009: 260-264), inherently political. Furthermore, at least in those instances in which the addressees of such attempts are formal political institutions (Hsieh (2009: 251) sees a responsibility for businesses to help establish just political, economic, legal and civic institutions), we are dealing with political activity in a narrow sense. In fact, this seems precisely the kind of political responsibility, which Smith also advances in his comment, since a duty to "further justice" or "to help constitute justice," as depicted by Smith (2013: 12), most likely requires political activity (either in a narrow or in a wide sense) at some level.

The political in a wide sense can be understood, in Iris Marion Young's (2004: 377) words, as

activity in which people organize collectively to regulate or transform some aspect of their shared social condition, along with the communicative activities in which they try to persuade one another to join such collective action or decide what direction they wish to take it.

Thus, political responsibility in this wide sense is communicative responsibility, that is, a responsibility to engage in such communicative 
processes in order to deliberate and decide on the collective courses of action needed to respond to specific problems. Perhaps the most prominent account of such political responsibility in a wide sense is Young's (2003, 2004) social connection model to political responsibility. Just like Hsieh's, the foundation of Young's account of political responsibility is moral. However, unlike Hsieh's, it not based on “do no harm" but on an agent's belonging to unjust structures and thus on his or her social connection to injustices which call for remedy. Also the argument formulated in my paper, as we will see shortly, belongs most fittingly to this particular strand of research on political responsibility as responsibility for political action.

\section{Human Rights Responsibility as Political Responsibility}

We can now have a look at how these different interpretations of political responsibility relate to human rights. For this purpose, Denis Arnold's (2010: 378-379) distinction between moral, political, and legal conceptions of human rights will be helpful. A moral conception of human rights, according to Arnold, holds that human rights are ethical demands or imperatives. A political conception of human rights holds that human rights are political demands, deriving from political agreements. A legal conception of human rights holds that human rights are legal demands grounded in positive law. Depicting rights as "demands," as Arnold does, implies their correspondence with respective responsibilities. Concordantly, a moral conception of human rights, as he argues, holds that respecting such rights is at minimum an ethical requirement, though it may be turned into a legal duty through regulatory, judicial, or administrative mechanisms (Arnold 2010: 379). Political conceptions of human rights correspond with political responsibilities (in the sense of politically grounded responsibilities). Thus, respecting such rights is at minimum a political requirement. They are binding on those agents "who are party to the agreement or who are legitimately subject to those who are party of the agreement” (Arnold 2010: 379). Political rights can, but must not be grounded in moral rights. They too can be turned into legal rights through the respective mechanisms. Finally, human rights stipulated in positive law give rise to legally enforceable duties.

The argument advanced in my paper is based on a conception of human rights not as political, but as moral rights. Thus, the requirements corresponding with such rights are, at minimum, moral. In 
other words, the arguments for corporate human rights responsibility advanced in my paper are grounded morally, rather than politically. The extent of such responsibilities depends, among other things, on an agent's capabilities. However, the relevant capabilities of multinationals are by far not limited to those narrowly associated with wealth creation, but extend far into the political realm. In fact, as David Vogel (2005: 171) confirms,

the most critical dimension of corporate responsibility may well be a company's impact on public policy. A company's political activities typically have far broader social consequences than its own practices.

Hence, precisely those capabilities needed to transform unjust structures into just ones (Young) and thus to promote (Hsieh) or further (Smith) just institutions seem to be distinctly political. And precisely those capabilities rest increasingly with companies today.

\section{Corporations as State-Like Institutions?}

To argue that, because of their extensive set of capabilities, multinationals have political responsibilities that extend beyond the mere duty not to violate human rights is a far cry from claiming they have the same responsibilities as states. Even though both institutions may have responsibilities in all three categories of respecting, protecting and realizing human rights, their actual responsibilities within those categories may differ substantially. It is one of the major takeaways of the debate on political CSR that multinationals increasingly have capabilities to address global (human rights) problems beyond what is possible for increasingly compromised nation states. It would be simplistic to look at such processes simply as companies replacing governments, all else equal. Rather, it is about a more fundamental reconfiguration and extension of the sphere of political action (Baur 2011: 24) and thus of the overlapping and interdependent political roles and responsibilities of a whole variety of institutional agents in what has been called the "post-national constellation" (Habermas 2001).

That multinational corporations are institutions of significant power is hardly disputed today. This power is both morally and politically relevant. Thus, while from a pragmatic point of view it may indeed be advisable to appease critics by avoiding "to conceptualize corporation as state-like actors" (Smith 2013: 12) or indeed to avoid 
any kind of reference to corporate political engagement, it seems that precisely from a moral perspective it is of little help to leave the growing political relevance of companies unaddressed.

Received 9 Mar 2013 / Posted 13 Mar 2013

\section{REFERENCES}

Arnold, D. 2010. "Transnational Corporations and the Duty to Respect Basic Human Rights.” Bus Ethics Q 20(3): 371-399.

Baur, D. 2011. NGOs As Legitimate Partners Of Corporations: A Political Conceptualization. Dordrecht: Springer.

Habermas, J. 2001. The Post-National Constellation: Political Essays. Cambridge: Polity Press.

Hsieh, N. 2009. "Does Global Business Have a Responsibility to Promote Just Institutions?”. Bus Ethics Q 19(2): 251-273.

Matten, D. and A. Crane. 2005. "Corporate Citizenship: Toward an Extended Theoretical Conceptualization.” Acad Mgmt Rev 30(1): 166-179.

Scherer, A. G. and G. Palazzo. 2007. “Toward a Political Conception of Corporate Responsibility: Business and Society Seen from a Habermasian Perspective.” Acad Mgmt Rev 32(4): 1096-1120.

Scherer, A. G. and G. Palazzo. 2011. "A New Political Role of Business in a Globalized World: A Review and Research Agenda.” J Mgmt Stud 48(4): 899-931.

Smith, J. 2013. “Corporate Human Rights Obligations: Moral or Political?”. Bus Ethics J Rev 1(2): 7-13.

Wettstein, F. 2012. "CSR and the Debate on Business and Human Rights: Bridging the Great Divide.” Bus Ethics Q 22(4): 739-770.

Vogel, D. 2005. The Market for Virtue: The Potential and Limits of Corporate Social Responsibility. Washington DC: Brookings Institution Press.

Young, I. M. 2003. "From Guilt to Solidarity. Sweatshops and Political Responsibility.” Dissent 50(2): 39-44.

Young, I. M. 2004. “Responsibility and Global Labor Justice.” J Pol Phil 12(4): 365-388. 